Chapman University

Chapman University Digital Commons

Film Studies (MA) Theses

Dissertations and Theses

Spring 5-19-2019

\title{
A Cauldron of Chaos and Cultivation: Rediscovering Disney Animation of the 1980s
}

Thomas Price

Chapman University, tprice@chapman.edu

Follow this and additional works at: https://digitalcommons.chapman.edu/film_studies_theses

Part of the Film and Media Studies Commons

\section{Recommended Citation}

Price, Thomas. "A Cauldron of Chaos and Cultivation: Rediscovering Disney Animation of the 1980s." Master's thesis, Chapman University, 2019. https://doi.org/10.36837/chapman.000112

This Thesis is brought to you for free and open access by the Dissertations and Theses at Chapman University Digital Commons. It has been accepted for inclusion in Film Studies (MA) Theses by an authorized administrator of Chapman University Digital Commons. For more information, please contact laughtin@chapman.edu. 
A Cauldron of Chaos and Cultivation:

Rediscovering Disney Animation of the 1980s

A Thesis by

Thomas Henry Price

Chapman University

Orange, California

Dodge College of Film and Media

Submitted in partial fulfillment of the requirements for the degree of

Master of Arts Film Studies

May 2019

Committee in charge

Nam Lee, Ph.D., Chair.

Dawn Fratini., Ph.D.

Kia Afra., Ph.D. 
This Thesis of Thomas Henry Price is approved
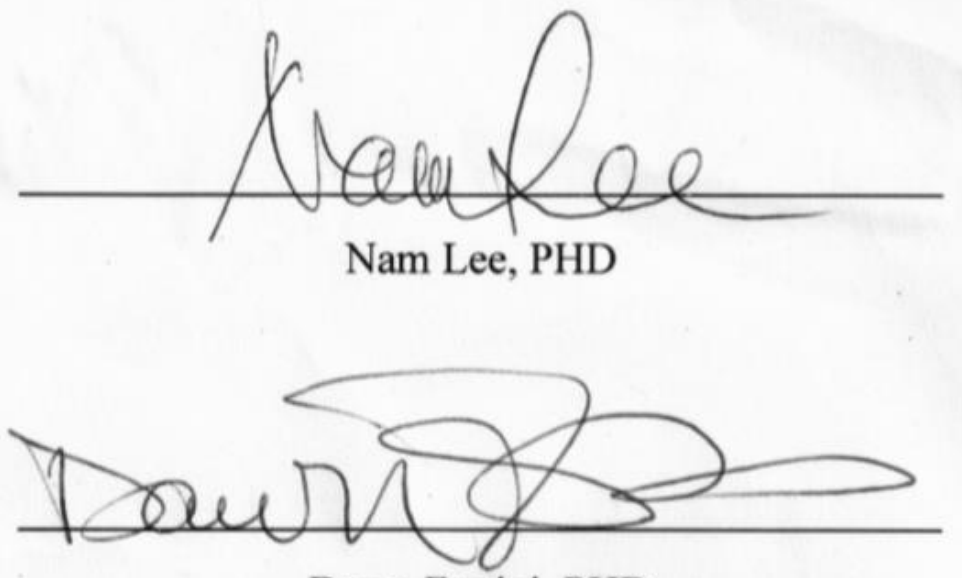

Dawn Fratini, PHD

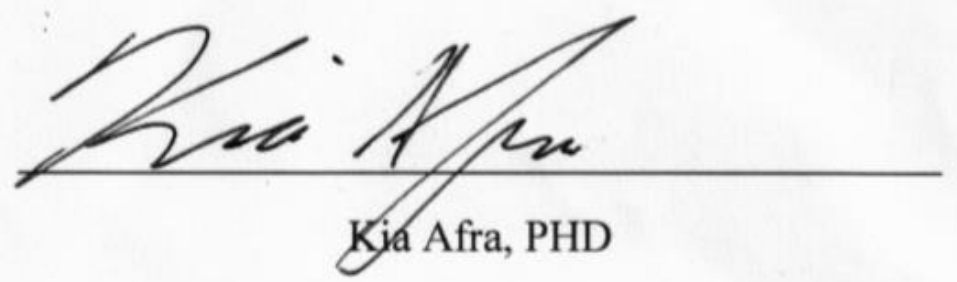

April, 2019 
A Cauldron of Chaos and Cultivation: Rediscovering Disney Animation of the 1980s Copyright @2019

by Thomas Henry Price 


\begin{abstract}
A Cauldron of Chaos and Cultivation: Rediscovering Disney Animation of the 1980s by Thomas Henry Price
\end{abstract}

This thesis examines the four transitional Disney animated features of the 1980s The Fox and the Hound (1981), The Black Cauldron (1985), The Great Mouse Detective (1986), and Oliver and Company (1988) — in order to reassess the significance of this period in Disney history. The Walt Disney Studio is internationally hailed for its animated features produced over the last eight decades, however, the animated films released in the 1980s have been ignored and neglected due to the negative evaluations of scholars and historians who favor Walt's era and the 1990s renaissance period. A closer examination of the films reveals that Disney was not in a dark age but one of experimentation, excisement, and exploration in contrast to the perceived notions. Each film contributed to Disney animation's return including a generational shift in creativity, application of computer animation, casting a celebrity as a voice-artist, and the use of theme songs and popular singers. These contributions were technically, thematically, and aesthetically important in reframing Disney's animated products for future audiences leading to the 1990s successes beginning with The Little Mermaid. 


\section{TABLE OF CONTENTS}

Introduction 1

The 1980s: From the "Dark Age" to the Era of Creative Innovation 5

The Fox and the Hound: Generational Shifts and Darker Themes 11

The Black Cauldron: Computer-animated Spectacles of Graphic Violence 15

The Great Mouse Detective: Movie Stars Voice Original Characters 21

Oliver and Company: Popular Songs and Singers 25

The Little Mermaid and the Next Generation of Disney Film 28

$\begin{array}{ll}\text { Conclusion } & 30\end{array}$

Works Cited 32

$\begin{array}{ll}\text { Bibliography } & 33\end{array}$

Filmography 35 


\section{$\underline{\text { Introduction }}$}

The 1980s were an innovative and eclectic time for American cinema as audience attendance peaked with a barrage of blockbuster films. ${ }^{1}$ Star Wars (1977, George Lucas), Jaws (1975, Steven Spielberg), Blade Runner (1982, Ridley Scott), and E.T. The Extraterrestrial (1982, Steven Spielberg) enticed and enchanted audiences with state-ofthe-art special effects and memorable plotlines never before seen in American cinema. However, while studios such as Twentieth Century Fox, Warner Brothers, and Paramount were earning millions at box-offices, the Walt Disney Studio found itself in a difficult time, stirring a cauldron of chaos. The problems arose as a result of a decreasing popularity of animation, changing technologies, creative differences within the studio, as well as losing younger audiences to the blockbuster phenomenon which made Disney's products seem obsolete. Disney's animated films of this time did not receive the praise that previous features upon which Walt Disney personally worked, beginning with Snow White and the Seven Dwarfs (1937, David Hand) and ending with The Jungle Book (1967, Wolfgang Reitherman), had decades earlier. This era has been considered by many to be one of the darkest periods in Disney history, yet, it was also an innovative and creative time in Disney filmography. The 1980s, when carefully examined, were not a troubled period for Disney but one of experimentation, exploration and excisement in

\footnotetext{
${ }^{1}$ Garin Pirina. "1985: The Last Great Year in Film for Kids and Young Adults." The Atlantic, Mar 6, 2015. Accessed August 11, 2018. http://www.theatlantic.com/entertainment/archive/2015/03/why-the-1980s-is-the-lastgreat-decade-in-youth-films/38525.
} 
which the company reframed animated products and cultivated newfound success. In sum, it was a period of creative and transformative chaos.

The seed for the ensuing chaos was planted in 1966 with the death of Walt Disney, who was the central creative visionary in the evolution of the company's animated films. This tragic passing led the Disney Studio into a prolonged period of transition and turmoil that would last into the late 1980s. The tumult, in turn, led to leadership shifts, loss of artists, diminished business strength and audience dissatisfaction. Furthermore, animated films released during this era received little to no critical recognition. According to animator Don Hahn, tensions were rising and it appeared as though "the wheels were coming off the cart," yet, it would lead to a new era, arguably greater than any that had gone before. ${ }^{2}$

During this post-Walt era, Disney's animated films were reimagined by a new generation of artists, who created filmic products based upon what Walt would have done while adding their own touch. After Walt Disney's death, the animation department continued for over a decade to create their products based on how Walt would make a film, whether it was character arcs, plot-orientation, or artistic design. Departing from Walt's ideas, however, in certain measures, not only increased, eventually, the quality of the animated films, but cut down the costs and time length for production. Indeed, the

${ }^{2}$ Waking Sleeping Beauty, dir. Don Hahn (2009; Burbank, CA: Disney DVD, 2010), DVD. This documentary film is the most valuable source of information on 1980s Disney animation as it features commentary from the people involved and original footage of the films being created. 
technologies utilized enhanced and reforged Walt Disney's formula for success while also reframing the look and tone for contemporary audiences. Hence, the 1980s is a crucial period that merits a re-evaluation and a renewed recognition within the history of Disney animation.

This thesis examines the transitional Disney animated filmography of the 1980s which includes The Fox and the Hound (1981, Richard Rich, Ted Berman), The Black Cauldron (1985, Ted Berman, Richard Rich), The Great Mouse Detective (1986, John Musker, Ron Clements, Dave Michener, Burny Mattinson), and Oliver and Company (1988, George Scribner), also concluding this period's analyses with an evaluation of The Little Mermaid (1989, John Musker and Ron Clements), which represents the culmination of the 1980s Disney animated films and their collective and creative production contributions. These films are analyzed technically, thematically, and aesthetically in order to highlight their importance and significance in the 1980s as well as their additions to the resurgence of Disney animation in the following decade. The 1980s were a pivotal period in the history of the Walt Disney Company resulting in artistic and directional shifts that reframed films for future audience enjoyment while cultivating contributions that would impact and influence the 1990s renaissance period.

The animated feature films released during the 1980s did more than present stories with special characters. The Fox and the Hound displays the explosion of youthful creativity the new generation of animators brought to Disney, as well as the embracement of darker themes. The Black Cauldron, on the other hand, presents Disney's application of computer animation as well as displaying more violent content. 
The Great Mouse Detective returned to the practice of casting a celebrity as a voice artist, which would carry on into the next decade, as well as a return to simple storytelling. Oliver and Company introduced theme music and the participation of popular singers, which would become a staple in subsequent blockbuster animations such as The Lion King (1994, Roger Allers, Rob Minkoff). The Little Mermaid concluded this period by combining all of the contributions made by the four animated films.

Moreover, the impact of the 1980s products continued to be felt in subsequent animated features, including Beauty and the Beast (1991, Gary Trousdale, Kirk Wise), and Aladdin (1992, John Musker, Ron Clements). As such, Disney's journey from chaos to cultivation is chronicled in these pivotal 1980s animated feature films and their artistic, technical and thematic forays, ultimately leading, in 1989, to a resounding return to critical and financial success. In order to highlight the historical significance of this body of film and the need for reassessment, this thesis first examines the ways in which scholars and critics have viewed or dismissed the 1980s as a dark age in Disney history. Following this, it looks at the pre-and early 1980s to contextualize the period within the larger struggle through which the Disney Company was going after Walt Disney's death. The textual analyses of the four selected animated features demonstrate and highlight technical, thematic, and aesthetic merit of each film and their contributions leading to Disney's resurgence in the 1990s. Disney's animation revival began with The Little Mermaid and continued with Beauty and the Beast, Aladdin, and The Lion King. 
The 1980s: From the "Dark Age" to the Era of Creative Innovation

Disney's animated films of the 1980s have largely been disregarded in the studies of Disney. Many sources regard this era as unproductive and in decline. For example, Charles Solomon asserts that Disney's animated films of the 1980s were unexciting and of inferior quality in their stories and creativity. ${ }^{3}$ In his documentary film on 1980s Disney, Waking Sleeping Beauty (2009), Don Hahn recognized the tumult: "from 1984 to 1994, a perfect storm of people and circumstances changed the face of animation forever. But it almost never happened." ${ }^{4}$ Legendary Disney animators Ollie Johnston and Frank Thomas, both tutored and mentored by Walt Disney, stated that the Disney Studio was a changed place by the early 1980s, that there was low morale, and that small groups of new animators were trying to "push scattered ideas for expanded opportunities and procedures to develop new talent." 5 The chaos, as noted by Johnston and Thomas, was a result of the Disney Studios' changing environment and artistic talent, both of which sought to reinvent the ways of animation. While Johnston and Thomas acknowledged the efforts of the animators, the results were not satisfactory and this further conveys that this was a period of decline. This commonly held view of 1980s Disney animation has thus eliminated much inquiry into what was, in fact, a transitional period. Solomon, Johnston and Thomas, while knowledgeable in the history of Disney animation, present negative

${ }^{3}$ Charles Solomon, Enchanted Drawings: The History of Animation (New York: Wings Books, 1994), 278.

${ }^{4}$ Waking Sleeping Beauty, dir. Don Hahn.

${ }^{5}$ Ollie Johnston and Frank Thomas, The Disney Villain (New York: Hyperion, 1993), 169. 
views of the 1980s, furthering the belief that the period was unimportant and one to dismiss. These interpretations, however, have inspired new scholars to reexamine 1980s Disney animation and its importance in a broader frame and with a refreshed lens.

It is only recently that some contemporary critics began to view the 1980s in a somewhat positive light instead of relying upon past interpretations. Bailey Cavender is one of these critics reevaluating the 1980s, however, she analyzes based upon which films have held up with the times and those that she believes should be forgotten. She argues that films such as The Great Mouse Detective and Oliver and Company are unappreciated gems in the Disney filmography while The Fox and the Hound and The Black Cauldron are too dark and/or emotional. ${ }^{6}$ Cavender's analysis remains largely on an aesthetic level. Despite referencing the 1980s on an historic basis, Cavender does not place the films in context of this period and relies on her own analyses of the products' significance. ${ }^{7}$ Historian Mindy Johnson interprets the 1980s as a significant period in Disney animation, however, her examination focuses upon the new technologies and, in particular, the contributions of women animators such as Linda Miller, Emily Jiuliano, and Tina Price, who have not received the credit deserved. ${ }^{8}$ Cavender and Johnson's analyses are vitally important in re-evaluating the positive elements of 1980s Disney animation. Building upon these recent studies, this thesis expands the scope of the

\footnotetext{
${ }^{6}$ Bailey Cavender, A Journey Through Disney: My Look Back Through Disney Canon (San Bernardino: Independently Published, 2018), 214-241.

${ }^{7}$ Cavender, 5-7.

${ }^{8}$ Mindy Johnson, Ink and Paint: The Women of Walt Disney's Animation (Los Angeles; Disney Deluxe Editions, 2017), 327.
} 
existing scholarship on this period by situating the 1980s within the history of Disney animation, especially vis-à-vis the legacy left by Walt, who exerted a substantial influence even after his passing. In fact, the history of creative shifts, reinventions, and forward momentum that had long been part of the Disney organization is represented in the films of this period.

Beginning in 1923, Walt Disney and his company reinvented the medium of animation, changing it from simple screen images produced for children's entertainment to full-length, widely appealing and story-driven features for all ages. With the 1937 release of Snow White and the Seven Dwarfs, Disney ushered in an unprecedented age of animation with a signature vision and touch that only concluded with the last film to bear Walt's personal imprint, The Jungle Book, in 1967. Walt's creativity and the talents of a team of animators known as the "nine old men" brought depth, pathos, comedy, action and heart into a canon of animated feature films for forty years. ${ }^{9}$ The animated films created at the Disney Studio succeeded as a result of a successful formula implemented by Walt, which, according to Jeffrey Katzenberg, former co-CEO, consisted of "a special story, memorable characters, and catchy songs." ${ }^{\text {"10 }}$ Many of Walt's greatest animated masterpieces utilized this formula. However, by the 1950's, Walt lost interest in the genre of animation and turned to new forms of entertainment such as live-action films, television and theme parks. ${ }^{11}$ Notwithstanding this, animated films continued to be made

\footnotetext{
9 John Canemaker, Walt Disney's Nine Old Men: and the Art of Animation (New York: Disney Hyperion, 2001), 7.

${ }^{10}$ Waking Sleeping Beauty, dir. Hahn.

${ }^{11}$ Ibid.
} 
by the studio and were both commercially and critically successful. Walt's unanticipated death, however, signaled difficult times ahead, leaving a void on many levels: personally, for his devoted employees; across the company, for his leadership and vision; and within the animation field and the film industry. This loss caused the Disney organization to lack clear artistic and technical direction for the next two decades. The immediate and shortterm productions after Walt's death continued to utilize his deeply experienced and trusted nine old men. During this period, the animation department produced harmless, sweet, and inexpensive animated films for children such as The Aristocats (1970, Wolfgang Reitherman), Robin Hood (1973, Wolfgang Reitherman), The Many Adventures of Winnie the Pooh (1977, John Lounsbery, and Wolfgang Reitherman), and The Rescuers (1977, John Lounsbery, Wolfgang Reitherman). Following the successful release of The Rescuers, which they felt was their finest product since Walt's passing, many of the nine old men retired, while Ollie Johnston, Frank Thomas and Wolfgang Reitherman stayed behind to work on one last film. However, several of these veterans had begun to train newcomers including former Disney animator Don Bluth along with Jon Pomeroy, Gary Goldman, Glen Keane and many others. ${ }^{12}$ Walt's son-in-law Ron Miller assumed the role as head of the studio at this time and strongly encouraged the animation department to recruit students from the company-owned California Institute of the Arts (CalArts), where many of the nine old men were instructors. These newcomers were readily embracing the changes in the film industry and were eager to show their talent and promise. ${ }^{13}$

\footnotetext{
${ }^{12}$ Solomon, 276.

${ }^{13}$ Ibid., 2.
} 
These changes inside the Disney organization were based upon retirements as well as new directions, reflecting company shifts and film industry preferences. Within the animation group, discontent led some to leave, including Don Bluth, who departed in 1979 over creative differences and disillusionment with the company's direction. ${ }^{14}$ The old ways and animators, as well as the film themes, once the foundation for success, were being replaced by new talent, techniques and tastes. In part, changes implemented were in response to a perceived stigma about animated movies, that they were made strictly for children. Indeed, a survey from the early 1980s revealed that teens wouldn't be caught dead seeing a Disney film. This much was clear: Disney's animation department was in dire need of change; animation technology was shifting and morale was plummeting. The seasoned animators had one collective foot in the past and the innovators and business game-changers had theirs in the future.

The new animators found that they were expected to adhere to the traditional Disney formulas. Hahn notes that he and his fellow animators "were full of pent- up youthful creativity that had to go somewhere," while Ron Clements recalls that despite having learned from the nine old men "there was this feeling we could be making better films." 15 Creative clashes and struggles to embrace the future while retaining the Disney brand struck the animation department. At this point, however, the department would receive much needed help from new business leaders. In 1984, Michael Eisner, Jeffrey

\footnotetext{
${ }^{14}$ Waking Sleeping Beauty, dir. Hahn.

15 Ibid.
} 
Katzenberg, Frank Wells, and Roy Edward Disney arrived and ushered in new business strengths and determination to resolve the animation department's struggles. Roy E Disney, Walt's nephew, specifically asked Eisner to let him have the animation department as he felt he knew the most about the group and was protective of it. ${ }^{16}$ Bluth's sudden departure caused Disney to delay the release of their upcoming animated feature The Fox and the Hound by seven months while the company began recruiting multiple animators from CalArts to fill the low number of artists at the studio. Disney's animation department now consisted of two-hundred artists/animators, including Don Hahn, John Lasseter, Ron Clements, John Musker, Mike Gabriel, Roger Allers, Andreas Dejas, Joe Ranft, and Tim Burton. These graduates of CalArts were selected for their skills and genius in animation as well as their willingness to embrace new technology, most notably computers. At this time, CEO Ron Miller, while trying to reach wider audiences, encouraged the animation department to embrace computers as he felt this presented the company with the opportunity to do films that were both unique and different. ${ }^{17}$ This resulted in the creation of Tron (1982, Steve Lisberger), which, according to Mindy Johnson, became the first film in which computer effects were combined with traditional animation and live-action. ${ }^{18}$ Nonetheless, the new animators continued to work on The Fox and the Hound, which was completed and released in 1981. This film launched Disney into a new decade of animation which brought continuing trials but also

\footnotetext{
${ }^{16}$ Ibid.

${ }^{17}$ Johnson, 327.

${ }^{18}$ Ibid.
} 
transitions, successes, and lessons to the company as it sought to reframe and refresh its products.

\section{The Fox and the Hound: Generational Shifts and Darker Themes}

Loosely based upon Daniel P. Mannix's novel of the same title, The Fox and the Hound was the first animated feature in which the new animators were given creative freedom. This sweet, poignant, and dramatic film centers its plot upon Tod, an orphaned fox cub, and Copper, a hound dog puppy, who form an unexpected friendship and vow to forever remain friends despite the fact that they are destined to become enemies. As they had done with previous animated stories, Disney deviated from Mannix's story and created a family-friendly plot filled with supporting characters such as Big Mama the Owl, Dinky the Sparrow, Boomer the Woodpecker, and Vixey the Vixen. The Fox and the Hound marks an explosion of youthful creativity in Disney's animation department. The new animators were placed right into training under the remaining old guard. ${ }^{19}$ Following the conclusion of training, the newcomers were given artistic license on the film's animated characters. One of these who demonstrated extraordinary creativity was Glen Keane, who animated the climactic fight between Copper, Tod and the bear which signaled his potential as a leading animator. ${ }^{20}$ Keane drew inspiration from previous animated fight sequences, such as the Tyrannosaurus rex and Stegosaurus scene in

\footnotetext{
19 Ibid.

${ }^{20}$ Rebecca Knowles, Disney: The Ultimate Visual Guide (New York: Dorling Kindersley, 2002), 81.
} 
Fantasia (1940, Ben Sharpsteen) to convey an epic moment reminiscent of former Disney animated products, displaying his artistic talent. Keane created an electrifying sequence that provided an edge to The Fox and the Hound's otherwise tame narrative. The Fox and the Hound also marked a return to drawing characters originally instead of basing them upon the personalities of their voice artists. One character who demonstrates this deviation is Amos Slade, who was not based upon his voice artist Jack Albertson, but drawn as a vicious, bullying old hunter. ${ }^{21}$ Disney's decision to draw their characters uniquely continued into the 1990s as the artists determined not to base their characters on the voice artists but instead rely upon their own artistic skills. The animators' creativity influenced The Fox and the Hound technically, yet, they were readily embracing darker themes that allowed Disney to depart from their usual family friendly fare and thematically shift the plot. The Fox and the Hound story marks a departure from previous animations with its dramatic opening, darker motif, and bittersweet ending. The film opens with shots of a vixen fleeing from a hunter and his hound through a forest while carrying her cub. After depositing her cub on a farm, the vixen flees only to be killed by the hunter. Disney had not opened an animated film in this violent manner since Snow White, which features a dramatic scene where the huntsman attempts to slay the innocent heroine but cannot bring himself to perform the deed. Thus, this beginning demonstrates the new animators' eagerness to experiment with novel stories by embracing the darker

\footnotetext{
${ }^{21}$ John Grant, Encyclopedia of Walt Disney's Animated Characters: From Mickey Mouse to Hercules (New York: Hyperion, 1998), 308-09.
} 
themes that Disney had been ignoring in favor of innocuous and non-threatening stories. The film's opening proved to be one of Disney's most dramatic sequences to date and emphasized that the new animators had the skills needed to heighten an animated film. As such, The Fox and the Hound presented a thematically different animated narrative which signaled Disney's foray into new territories of storytelling. However, the film still revolved around traditional perky animated characters. Boomer the Woodpecker, Dinky the Sparrow, and Squeaks the Caterpillar are presented as supporting characters reminiscent of the loveable mice and lazy cat of Cinderella (1950, Clyde Geronimi) and used largely for comedic relief and not narrative enhancement. These traditional supporting players add a childlike innocence to the narrative until it takes a dramatic turn during the latter half. This was the last animated film in which the remaining nine old men were involved before passing the torch to the new generation of animators. While the film grossed an impressive $\$ 50$ million USD at the box office, it received mixed reviews from critics. Roger Ebert noted that "for all of its familiar qualities, this movie marks something of a departure for the Disney studio, and its movement is in an interesting direction" and that "The Fox and the Hound is one of those relatively rare Disney animated features that contains a useful lesson for its younger audiences. It's not just cute animals and frightening adventures and a happy ending; it's also a rather thoughtful meditation on how society determines our behavior." 22 Thus, the decision to

${ }^{22}$ Roger Ebert, "The Fox and the Hound Review," Movie Review, January 1, 1981. Accessed October 2, 2018. http://www.Rogerebert.com/reviews/the-fox-and-the-hound$\underline{1981}$ 
utilize mature themes surprised critics as Disney animation was typically hailed for generating appealing animated features for all age groups. The film ultimately was a hybrid that combined children's entertainment with expanded content that adults would be able to enjoy. The Fox and the Hound became Disney's first animated film to plot their characters around that idea. The film's message of never-ending friendship would inspire future Disney animated films, particularly The Little Mermaid, which, according to Peter Schneider, brought in by new management as vice president of the animation department, contained a strong and contemporary theme of parents relinquishing control over children and letting them live their own lives. ${ }^{23}$ As such, with its new approach of adding deeper themes to the plots of animated films, Disney ventured into new territories in filmmaking.

The technical, thematic, and aesthetic qualities make The Fox and the Hound a highly detailed animated film. It was created during a difficult period in which Disney was torn between following the old ways or embracing the new and darker themes present in Hollywood films generally. However, The Fox and the Hound turned out to be an important part of Disney animation as it marks a new creative attempt by the younger generation. Following The Fox and the Hound's release, Disney had already begun developing an epic dark fantasy film that would bring about a major culture clash: The Black Cauldron. ${ }^{24}$

${ }^{23}$ Jeff Kurtti, The Art of The Little Mermaid (New York: Hyperion, 1997), 159.

${ }^{24}$ Waking Sleeping Beauty, dir. Hahn. 


\section{The Black Cauldron: Computer-Animated Spectacles of Graphic Violence}

The Black Cauldron spent several years in production and went millions of dollars over budget. ${ }^{25}$ While the film signaled another significant departure from Disney's traditional fare, it marked the first time that computer animation was applied to a production by the Disney studio. The computer animation allowed animators to digitally convert two-dimensional objects into three-dimensional images via computer while also cutting down on production costs. The Black Cauldron's plot is based upon The Chronicles of Prydain book series by Lloyd Alexander, which was inspired by Welsh mythology. Historically, The Black Cauldron was Disney's most controversial animated film to date as it contained dark and scary content that could have earned a PG-13 or R rating from the Motion Picture Association of America. Created during a chaotic period in Disney history, The Black Cauldron was subjected to multiple changes both within the animation department and in the hands of corporate figures. Despite having a disjointed plotline and weakly developed characters, The Black Cauldron technically made achievements in animation and art direction that make it a visually dazzling film.

The incorporation of computer animation in The Black Cauldron proved beneficial in production, particularly in animating objects such as an old boat, which was digitally generated. ${ }^{26}$ Another scene to digitally convert an object is the one in which the Horned King activates the black cauldron and resurrects a grotesque army of deathly

\footnotetext{
${ }^{25}$ Ibid.

${ }^{26}$ James B. Stewart, Disney War (New York: Simon and Schuster, 2005), 68.
} 
skeletal soldiers. The cauldron itself was a digitally created object to give it a threedimensional appearance. The Black Cauldron also made use of animation photo transfer process (APT) which involved "taking an animated drawing and photographically transferring it to a cel" which cut down costs. ${ }^{27}$ Despite the technological challenges presented by APT, it was applied to the tracing and coloring of darker characters such as the Horned King, his assistant, Creeper, the gwythaint dragons, and the king's henchmen, which provided them with authentic appearance. ${ }^{28}$ The Black Cauldron advanced Disney animation during the 1980s in its application of computer animation and animation photo transfer process to move away from the old artistic and technological methods used by Walt and the nine old men. The film not only made technological advancements but went on to change the culture of Disney animation as well.

Unlike The Fox and the Hound, which thematically features a strong story and likeable characters, The Black Cauldron presents a tangled narrative with mostly human characters, which are harder to animate than animals. ${ }^{29}$ As a result, the film can be perceived as a jumble of attempts to create a film that displays impressive examples of animation not seen before. According to Solomon, the moment where Taran, the protagonist, and his oracular pig, Hen Wen, are attacked by the gwythaints shows an almost feral strength while demonstrating animation's ability to render pure fantasy elements. ${ }^{30}$ Yet, Disney animation inserted moments of comic relief and minor

${ }^{27}$ Johnson, 331.

${ }^{28}$ Ibid.

${ }^{29}$ Solomon, 278.

${ }^{30}$ Ibid. 
characters to provide The Black Cauldron with a family friendly feel that distracts from the plot. During one scene, the main characters stumble upon the home of the fair folk, who are mostly portrayed as childish in appearance, while Doli, the grumbling assistant to the king, is reminiscent of Grumpy from Snow White. Thematically, this scene, along with characters such as Gurgi, the man beast, weakens the plot, points out animation's transition to embracing the new, while referencing the older content. Nonetheless, The Black Cauldron embraces an attempt to venture into fantasy worlds, although darker than ever before. It appears that Disney animators who worked on The Black Cauldron were compelled to emphasize the fantastical world of Prydain more than to keep the plot moving. This is evident in the lavish backgrounds illustrated by artist Mel Shaw. Stylists like Shaw "were not supposed to concern themselves with the details of making the picture. They were trying to create a way of visualizing the whole concept so that it would be attractive and fresh." ${ }^{31}$ As such, The Black Cauldron is detailed with beautiful forests, mountains, valleys and castles but is weak in the development of characters. Disney's attempt at creating a dark fantasy film resulted in a lavish product that suffered from plot holes, lack of character development, and overly dramatic sequences. The Black Cauldron spent nearly a decade in production and went through multiple changes in plot and content in order to provide the film with an attempt at a broader appeal. Originally put into pre-production in the early 1970s, The Black Cauldron was eventually

${ }^{31}$ Ollie Johnston and Frank Thomas, The Illusion of Life: Disney Animation (New York: Disney Editions, 1981), 191. 
passed down to a new generation of animators. However, the film was created at a time when the management of the Disney Company was in turmoil, revenues were declining, and when Disney sought to create films for more mature viewers since most, particularly teens, scorned anything released with the Disney label as children's entertainment. ${ }^{32}$ Ultimately, many animators, including Andreas Dejas, John Musker, and Tim Burton, felt that The Black Cauldron's production came during an unsettled time and that the film was too dark and the narrative misguided. ${ }^{33}$ Yet, they believed that this film had potential to become an animated blockbuster similar to that of Star Wars. However, Black Cauldron would go through an extensive rewrite after being screened for Eisner, Katzenberg, Roy E. Disney, and Wells.

Katzenberg was shocked by the product, particularly by the original opening sequence in which a dragon swoops down and sinks its claws into a little boy. More importantly, Katzenberg could not understand the story and felt that the picture was dark, foreboding and not suitable for small children. After the screening he declared "this has to be edited" despite the objections from the producer Joe Hale who claimed "animated films can't be edited" as the process was not the same as live-action films. ${ }^{34}$ But, Katzenberg's mind was made up; he knew that The Black Cauldron represented Disney's attempt to give their animated films an edge and a contemporary feel. ${ }^{35}$ He personally

\footnotetext{
${ }^{32}$ Bob Thomas, Disney's Art of Animation: From Mickey Mouse to Beauty and the Beast (New York: Hyperion, 1991), 114.

${ }^{33}$ Ibid.

${ }^{34}$ Stewart, 68.

${ }^{35}$ Ibid., 69.
} 
took the film into an editing room and cut between twelve to fifteen minutes, which some animators felt hurt the picture. He might have edited more had Roy E. Disney not stepped in. By the time it completed production, The Black Cauldron cost $\$ 44,000,000$, a shockingly high price for an animated feature film, and the results would not be positive. Finally reaching theaters on July 24, 1985, The Black Cauldron became a major boxoffice failure as it only grossed between 21 to 25 million dollars resulting in a twenty some million-dollar loss for Disney. To make matters worse, The Care Bears Movie (1985, Arna Selznick), produced by The Metro Goldwyn Meyer Studio, beat The Black Cauldron out financially. ${ }^{36}$ Johnston and Thomas recalled that audiences in 1985 found The Black Cauldron artistically mesmerizing but also confusing and overly somber in tone. ${ }^{37}$ Disney seemed directionless but its application of computer animation inspired the company to continue creating digitally.

The Black Cauldron was Disney's first film to apply computer animation and this technology would inspire the artists to animate objects in subsequent films such as Oliver and Company, transforming cars and buildings into computerized images. Yet, critics and viewers have tended to either forget and/or ignore The Black Cauldron as a result of its lack of appeal, darker tones, and weak plot/characters. Despite its lack of universal acclaim, The Black Cauldron deserves higher recognition as an important film of 1980s Disney culture and a project that helped a team of animators wake up the sleeping beauty

\footnotetext{
${ }^{36}$ Waking Sleeping Beauty, dir. Hahn.

37 Ibid.
} 
that was Disney's former glory. As well, on the business side, prior to The Black Cauldron's release, Disney's animation department received bad news in December 1984, when Roy E. Disney sent out a memo explaining that they would need to vacate their building.

Katzenberg decided that he wanted the animation building to house the studio's successful live-action department, which had experienced multiple commercial successes with films like Splash (1984, Ron Howard). The animation building was an historic monument where Walt Disney had created masterpieces such as Cinderella and Peter Pan (1953, Clyde Geronimi). ${ }^{38}$ Don Hahn recalls "there was no meeting, no debate just this memo...I guess Roy didn't want the confrontation. On the last day 200 frightened people, the remnants of Disney's once great animation studio, gathered on the steps of the old animation studio for one photo before we left." 39 The animators were moved to a building in Glendale that was replete with terrible conditions, but, despite being confined to cubicles, the animators actively communicated ideas. One day Katzenberg called a meeting for the animators to air their concerns and stated that they could hit him with anything as he felt that "he had rhino skin." One artist said, "we don't think you know what you're doing." Katzenberg responded, "I am here and not going away and I am more than happy to learn and take the time... but the last couple of animated movies were not good. ${ }^{40}$ Katzenberg was determined to restore Disney's animated movies and

${ }^{38}$ Waking Sleeping Beauty, dir. Hahn.

${ }^{39}$ Ibid.

40 Ibid. 
brought on Peter Schneider as Vice President over animation. Schneider was tasked with changing the face and product of Disney animation. Schneider wondered "why are we punching time clocks, why are we making our own paint, why can't we update our animation pegs, what are we doing about training?" ${ }^{41}$ As a result of Schneider's tenacity, Disney began updating their technology, skills, and emphasized teamwork, thus boosting the production of an animated feature film initially called Basil of Baker Street, later retitled The Great Mouse Detective.

\section{The Great Mouse Detective: Movie Stars Voice Original Characters}

Based on Eve Titus's book Basil of Baker Street, The Great Mouse Detective proved to be a much more pleasurable experience for Disney animation. Unlike with The Fox and the Hound and The Black Cauldron, the animators were given unlimited creative freedom on this picture. The Great Mouse Detective was conceived and designed differently than the previous two films in that it was meant to be funny, light-hearted, fun, and imbued with the charm and whimsy of the Monty Python comedy group. ${ }^{42}$ It was Schneider who felt that the title Basil of Baker Street was not marketable and insisted that it be changed to The Great Mouse Detective to entice audiences. While The Great Mouse Detective made technological innovations, particularly in computer effects, it also introduced a technique that had been previously utilized in Walt's era and would be carried into the 1990s renaissance period: casting a recognizable celebrity as the voice of

\footnotetext{
${ }^{41}$ Ibid.

${ }^{42}$ Johnston and Thomas, The Disney Villain, 175.
} 
a leading character. This replaced the department's traditional method of basing an animated character upon the voice artist, commonly used as a production cost-saving method. Throughout Disney's history, the animation department cast both famous and unknown actors in their animated feature films. Celebrities like Bing Crosby were featured in The Adventures of Ichabod and Mr. Toad (1949, James Algar) while singers and actors such as Peggy Lee, Phil Harris, and George Sanders were cast in films such as Lady and the Tramp (1955, Clyde Geronimi), and The Jungle Book. However, while the casting of these celebrities appealed to adult audiences who were familiar with them, children would not recognize nor connect with them. During the 1980s, however, children were exposed to new forms of media such as multiple television channels and could familiarize themselves with classic stars of the past and present. During the production of The Great Mouse Detective, Disney decided to return to this practice and cast former, yet, iconic horror actor Vincent Price as the villain Ratigan. This character was based upon the villain Moriarity from the Sherlock Holmes stories and on a nineteenth century painting of a man wearing a fancy black coat while smoking a cigarette on a holder. ${ }^{43}$ Vincent Price, who realized a life-long dream of voicing a Disney animated character, nearly stole the show making him a memorable villain. This change not only allowed Disney to introduce a new character who was emotional, theatrical, and confident in his abilities, but also inspired the animation department to begin casting film stars as voice actors in hope of increasing attendance. ${ }^{44}$ This casting of recognizable

${ }^{43}$ Ibid., 176.

${ }^{44}$ Ibid. 
actors would continue to be utilized in upcoming films such as Oliver and Company and the hugely popular Aladdin, which capitalized on Robin Williams performance as the genie. Following the inclusion of Vincent Price as a voice, The Great Mouse Detective inspired Disney to cast more contemporaneously known actors as voice artists in order to appeal to audience preferences. At the same time, Disney was looking at technological changes, attempting to cut down on production costs by merging two-dimensional and three-dimensional animation together via computer animation. The company realized that utilizing computer animation was key and The Great Mouse Detective became the first film to merge drawings with computer generated backgrounds. This technique was primarily applied to the climactic fight between Basil and Ratigan inside the clockwork of Big Ben. Animator Tina Price notes that Disney achieved the two-minute sequence by "using an old IMI Computer and hand-feeding the paper into a plotter [printer]" and then, "transferred via Xerox onto large-format (twenty-four-field cels), which were then handpainted." 45 The Great Mouse Detective successfully achieved a new form of animation which both reduced costs and blended $2 \mathrm{D}$ and $3 \mathrm{D}$ effects together to achieve a breathtaking animated sequence with enhanced theme and impact. In addition to its digital backgrounds and Vincent Price's voice, this film features a cast of likeable characters who were designed with originality and to appeal to all audiences. The protagonist Basil was designed as a Sherlock Holmesian mouse to whom audiences would warm. Supporting characters such as Dr. Dawson, Olivia Flaversham, and Fidget

\footnotetext{
45 Johnson, 336.
} 
the bat became thematically stronger through their voice-artists and the creative freedom Disney gave their animators. This practice would continue into the 1990s with The Rescuers Down Under (1990, Mike Gabriel), which features original and well-developed characters. Therefore, The Great Mouse Detective achieved success as result of unique characters, yet, returned to Disney's original form of storytelling, employing a simple plot laced with all-ages humor. The Great Mouse Detective's plot contains essential elements for effective narrative, including universally appealing characters and a theme that translated well to animation. The story unfolds through the eyes of the characters and there is also a blend of light and dark themes. However, in an updated twist, some more adult content, such as smoking and drinking, along with a suggestive "strip tease" number entitled "Let Me Be Good to You" was inserted. The Great Mouse Detective was able to appeal to a broader audience as had been attempted with The Black Cauldron. The result was a well-earned success. The Great Mouse Detective was theatrically released in 1986 and opened to good reviews and respectable box office. Yet, at the same time, there was a new threat in the field of animation: Steven Spielberg teamed with Don Bluth to create An American Tail (1986, Don Bluth), which became the highest grossing animated film not produced by Disney. It bested The Great Mouse Detective at the box office by about 22 million dollars. ${ }^{46}$ Despite the blow, Disney was slowly finding its way back, particularly thanks to Peter Schneider who allowed filmmakers to pick their own teams based upon connection and collegiality. ${ }^{47}$ Through its technological, thematic, and

46 Waking Sleeping Beauty, dir. Hahn 47 Ibid. 
aesthetic components, The Great Mouse Detective became an innovative and original film that helped return Disney to success. Indeed, at this point, the animation staff was eagerly submitting ideas for films, in what Jeffrey Katzenberg called a "gong show," an irreverent television series of the time. Creative freedom was not just welcome but actively encouraged, another indication of growing strength and renewed value for both employees and product. Disney's animation department began hosting an internal event where any staff from secretaries to janitors could come in and pitch their ideas in this "gong show". During these gatherings, the Studio green-lit films such as Pocahontas (1995, Eric Goldberg, Mike Gabriel), although The Little Mermaid was “gonged” at first for appearing too similar to Splash. Simultaneously, a new group of artists who had worked on the film Who Framed Roger Rabbit (1988, Robert Zemeckis) in London were brought back to Burbank and put to work on Oliver and Company and The Little Mermaid. This fresh and young international talent would produce commercially successful films for years to come.

\section{Oliver and Company: Popular Songs and Singers}

Oliver and Company became part of Disney's plan to distribute a new animated film every year. Ever since The Black Cauldron underperformed at the box office, Disney was eager to reinvigorate the public's taste for their animated films as many had lost interest. Part of the answer to the problem lay in Hollywood's technique of blending contemporary entertainment, particularly popular music or stars, into mainstream cinema. Disney decided to give Oliver and Company a current feel by setting the plot in 1980s New York City. 
Katzenberg felt that the film deserved to have songs composed and performed by singers of the 1980s and as such he brought on Huey Lewis and Billy Joel. Each of these popular singers sang a song in the film. ${ }^{48}$ Huey Lewis's performance of "It's Always Once Upon a Time in New York City" provided the film with an ideal opening: a relatable story set to a song sung by a modern artist. This was Billy Joel's first voice-acting experience, however, his performance as Dodger became an astonishing success for the film and for Disney, who found that not only could Joel sing, but act, too. The casting of Joel inspired the crew of Oliver and Company to bring on other celebrities, including Bette Midler, who provided the character Georgette with dramatic and theatrical flair that was exciting and invigorating. ${ }^{49}$ Not only did these performers bring their respective characters to life, they also lent their vocal strength and theatricality to a selection of original songs. This marked an attempt to appeal to broader audiences, and as such, featuring famous performers proved beneficial to the picture. Oliver and Company marks Disney's return to casting popular musical celebrities as voice-artists and composing contemporary musical scores. This practice inspired the company to continue casting other celebrities in future films like The Lion King, which includes a selection of songs composed by Elton John. Oliver and Company's other contributions to 1990s Disney animation include a continued application of computer animation to enhance the look of an animated feature film. Oliver and Company created cityscapes, cars, buses, sewer pipes, bridges, and a

\footnotetext{
${ }^{48}$ Stewart, 89.

${ }^{49}$ Grant, 337.
} 
piano through computers. This gave the film a depth not possible in regular animation and provided musical sequences such as "Why Should I Worry" a smoother appearance that was absent in earlier films like The Black Cauldron. Another sequence to utilize computer generated images is "Perfect Isn't Easy" which, according to Glen Keane, involved placing a camera in front of a computer, focused upon Georgette's feet, thus giving a sweeping appearance reminiscent of the Busby Berkeley musical films of the 1930s. ${ }^{50}$ The technical achievements of Oliver and Company inspired Disney to continue using computers to create astonishing new animated sequences and backgrounds in 1990s Disney films, including Beauty and the Beast. Therefore, Oliver and Company further developed computer animation unlike The Black Cauldron and The Great Mouse Detective, both of which only applied this animation to sequences. Thematically, this film marks a return to Disney’s animal-based tales with creatures who are both anthropomorphic and realistic, while aesthetically incorporating contemporary culture. Characters such as Oliver the kitten are similar to past animal characters, with his wide eyes and childish innocence, yet, becoming a more contemporary character through both the animation team and the voice of child celebrity Joey Lawrence. However, Oliver and Company also introduced a cadre of unique supporting characters, most prominently Tito the Chihuahua. He became a likeable side character with lots of personality, a result of his voice by Cheech Marin, who only read about 75 percent of the lines given to him. ${ }^{51}$

${ }^{50}$ Oliver and Company, dir. George Scribner, bonus feature (1988, Burbank, CA: Disney DVD, 2008), DVD.

${ }^{51}$ Solomon, 338. 
Thus, Disney animation allowed their voice artists to add their own touch to characters, particularly ad-libing, which would carry on into the 1990s. Oliver and Company represents the conclusion to Disney's transitional period and the beginning of a yearly release schedule, thus, the film serves as an ending and a beginning much like The Fox and the Hound had done seven years prior. Years of experimentation, excisement, and exploration finally paid off when Oliver and Company was released to good reviews. Debuting on November 18, 1988, Oliver and Company faced competition from Bluth's The Land Before Time (1988, Don Bluth), which opened the same day. Within a few months, Oliver and Company earned over \$53 million domestically which was a record for an animated film in its initial release. ${ }^{52}$ Oliver and Company's casting of popular celebrities and incorporation of theme music reframed Disney animation methods and intentions. Also, the utilization of computer animation improved the quality of the film and Disney's imbuing the animal characters with a modern flair reinvigorated the public's interest in Disney. Proving that they could capture the attention of viewers young and old, Disney animation exploded in creativity once again with Oliver and Company's successful release and the promising talent of animators put to work on the new film The Little Mermaid.

\section{The Little Mermaid and the Next Generation of Disney Film}

Disney had not produced an animated fairy tale since Sleeping Beauty (1959, Clyde Geronimi) which was a commercial failure upon its release in 1959. In the mid-

52 Ibid., 90. 
1980s, Disney decided to return to the fairy tale when Ron Clements submitted his idea of transforming Hans Christian Andersen's story The Little Mermaid into an animated feature. Clement's treatment of Andersen's fable was longer and featured a strong villain, Ursula the sea witch, along with a happy ending where the heroine is united with the prince she loves. Once again, Disney purposefully deviated from an original story and imbued it with lively characters and resonating songs and music. While Little Mermaid's characters were important, Disney specifically emphasized that music would be a key element in the plot, and it was Jeffrey Katzenberg who recruited off-Broadway song writing team Howard Ashman and Alan Menken to compose the songs and score for the film. They felt that the heart of the film lay in the song "Part of Your World," which Katzenberg wanted to cut because school age children got restless at an early showing. He was persuaded, largely by Keane, to keep it. ${ }^{53}$ The Little Mermaid represented a renaissance as artists were given creative freedom that redefined the medium of animated films. Indeed, The Little Mermaid was not just successful but wildly so. Its performance commercially, its evaluations critically, and the collateral products generated ushered in an age of animation that was essentially unprecedented. Yet, this triumph did not then, and has not since, rightfully referenced the components from the trial and error films of the 1980s that coalesced to create it. Without the "gong show," Katzenberg's almost desperate attempt to reignite the Disney fireworks of animation, this little mermaid would never have emerged from the sea. Arguably, however, The Little Mermaid is not a film of

${ }^{53}$ Waking Sleeping Beauty, dir. Hahn. 
the 1980s transitional era, but a bookend to that decade and the catalyst for the next decade. From this film sprung the ensuing even greater successes. Beauty and the Beast changed the history of Disney animation when it received six Academy Award nominations including Best Picture of 1991. During the film's company premiere, Roy E. Disney expressed his amazement when he stated that he was so proud of not just the animators' accomplishments on Beauty and the Beast, but how the animation department evolved from 200 frightened people wondering if they would have jobs the next day to world-renowned artists. ${ }^{54}$ The following year, Aladdin opened on Thanksgiving weekend 1992 and became the first animated film to gross over \$200 million in an opening, while The Lion King premiered two years later and was deemed Disney's most successful product yet. ${ }^{55}$ Peter Schneider felt that "these movies became once again the heart and soul of the Disney company; they rallied around them, they became characters and rides in the park...we could do no wrong... everything we touched turned to gold; every movie was bigger than the last movie." ${ }^{56} \mathrm{~A}$ decade of chaos had ended with a new construct.

\section{$\underline{\text { Conclusion }}$}

From the early 1980s to the late 1990s, Disney animation shifted from an unsure and struggling department to an artistically prosperous and incredibly successful juggernaut. Disney's animated films of the 1980s highlight the innovative steps taken by the new generation of animators. The Fox and the Hound, The Black Cauldron, The

\footnotetext{
54 Ibid.

55 Ibid.

56 Ibid.
} 
Great Mouse Detective, and Oliver and Company were not just films but catalysts and progressives that contributed to the successes of Disney's 1990s animated films. The Fox and the Hound contributed creative freedom in Disney animation as well as utilizing darker themes in their films. The darker themes featured in Fox and the Hound were applied to the plots of 1990s Disney animated films like Hunchback of Notre Dame, which opens with a grim and violent chase sequence. The Black Cauldron inspired the use of computer animation in all 1990s animated films, particularly in Hercules (1997, John Musker, Ron Clements), which digitally animated objects such as a monstrous hydra. The Great Mouse Detective inspired Disney to cast film stars as voices, as in Aladdin with Robin Williams cast as the genie, wildly popular with audiences. The release of Oliver and Company prompted Disney's animation department to provide films with theme music as well as incorporating popular singers like Elton John for The Lion King. The four animated films of the 1980s did not just culminate in the creation of The Little Mermaid, but in the productions of all 1990s Disney animation products. Walt Disney once said, "it seems to me that we have a lot of story yet to tell" and this rings true in both the past and present history of the Disney Company. Without this period of adolescence, where the company and the animated films grew from child-centric to universally oriented, there would not have been the necessary, albeit painful, development. Disney's four transitional animated films of the 1980s have been and should continue to be a legitimate part of the company's rich and detailed history: they had a lot of story to tell. 


\section{Works Cited}

Canemaker, John. Walt Disney's Nine Old Men and the Art of Animation. New York: Disney Hyperion, 2001.

Cavender, Bailey. A Journey Through Disney: My Look Back Through Disney Cannon. Independently Published, 2017.

Ebert, Roger. "The Fox and the Hound." Movie Review, January 1, 1981. Accessed October 2, 2018. http://www.Rogerebert.com/reviews/the-fox-and-the-hound1981.

Grant, John. Encyclopedia of Walt Disney's Animated Characters: From Mickey Mouse to Hercules. New York: Hyperion, 1998.

Johnson, Mindy. Ink and Paint: The Women of Walt Disney's Animation. Los Angeles: Disney Editions, 2017.

Johnston, Ollie and Frank Thomas. The Illusion of Life: Disney Animation. New York: Disney Editions, 1981.

Johnston, Ollie and Frank Thomas. The Disney Villain. New York: Disney Hyperion, 1993.

Kurtti, Jeff. The Art of The Little Mermaid. New York: Hyperion, 1997.

Knowles, Rebecca. Disney: The Ultimate Visual Guide. New York: Dorling Kindersley, 2002.

Pirnia, Garin. "1985: The Last Great Year in Film for Kids and Young Adults.” The Atlantic, Mar 6, 2015. Accessed August 11, 2018. http://www.theatlantic.com/entertainment/archive/2015/03/why-the-1980s-is-thelast-great-decade-in-youth-films/38525/.

Solomon, Charles. Enchanted Drawings: The History of Animation. New York: Wings Books, 1994.

Stewart, James B. Disney War. New York: Simon and Schuster, 2005.

Thomas, Bob. Disney's Art of Animation: From Mickey Mouse to Beauty and the Beast. New York: Hyperion, 1991. 


\section{Bibliography}

Artz, Lee. "Animating Hierarchy: Disney and the Globalization of Capitalism." Global Media Journal (2003) Volume 1.

Burton, Tim and Mark Salisbury. Burton on Burton Second Revised Edition. United Kingdom: Farrar, Straus, and Giroux, 2006.

Canemaker, John. Walt Disney's Nine Old Men: and the Art of Animation. New York: Disney Hyperion, 2001.

Cavender, Bailey. A Journey Through Disney: My Look Back Through Disney Cannon. Independently Published, 2017.

Ebert, Roger. "The Fox and the Hound.” Movie Review, January 1, 1981. Accessed October 2, 2018 http://www.Rogerebert.com/reviews/the-fox-and-the-hound1981-

Grant, John. Encyclopedia of Walt Disney's Animated Characters: From Mickey Mouse to Hercules. New York: Hyperion, 1998.

Johnson, Mindy. Ink and Paint: The Women of Walt Disney's Animation. Los Angeles: Disney Editions. 2017.

Johnston, Ollie and Frank Thomas. The Illusion of Life: Disney Animation. New York: Disney Editions, 1981.

Johnston, Ollie and Frank Thomas. The Disney Villain. New York: Disney Hyperion, 1993.

Jones, Amani. “The 9 Eras of Disney Animation.” Odyssey, November 28, 2016.

Accessed October 11, 2018. http://www.disneyavenue.com/2015/08/the-7-erasof-disney-filmmaking.html.

Kurtti, Jeff. The Art of The Little Mermaid. New York: Hyperion, 1997.

Knowles, Rebecca. Disney: The Ultimate Visual Guide. New York: Dorling Kindersley, 2002.

McMahan, Alison. The Films of Tim Burton: Animating Live Action in Contemporary Hollywood. New York: Continuum, 2006. 
Pirnia, Garin. "1985: The Last Great Year in Film for Kids and Young Adults.” The Atlantic, Mar 6, 2015. Accessed October 2, 2018. http://www.theatlantic.com/entertainment/archive/2015/03/why-the-1980s-is-thelast-great-decade-in-youth-films/38525.

Schickel, Richard. The Disney Version: The Life, Times, Art and Commerce of Walt Disney. Chicago: Elephant Paperbacks, 1997.

Solomon, Charles. Enchanted Drawings: The History of Animation. New York: Wings Books, 1994.

Stewart, James B. Disney War. New York: Simon and Schuster, 2005.

Thomas, Bob. Disney's Art of Animation: From Mickey Mouse to Beauty and the Beast. New York: Hyperion, 1991.

Wasko, Janet. Understanding Disney: The Manufacture of Fantasy. Cambridge, UK: Polity, 2001. 


\section{Filmography}

Allers, Roger, Rob Minkoff, dir. The Lion King. 1994; Burbank, CA: Walt Disney Home Video, 2011. DVD.

Berman, Ted, Richard Rich, dir. The Fox and the Hound. 1981; Burbank, CA: Walt Disney Home Video, 2006. DVD.

Berman, Ted, Richard Rich, dir. The Black Cauldron. 1985; Burbank, CA: Walt Disney Home Video, 2010. DVD.

Clements, Ron, John Musker, dir. Aladdin. 1992; Burbank, CA: Walt Disney Home Video, 2004. DVD.

Hahn, Don. dir. Waking Sleeping Beauty. 2009; Burbank, CA: Walt Disney Home Video, 2010. DVD.

Michener, Dave, Burny Mattinson, John Musker, Ron Clements. dir. The Great Mouse Detective. 1986; Burbank, CA: Walt Disney Home Video, 2010. DVD.

Musker, John, Ron Clements. dir. The Little Mermaid. 1989; Burbank, CA: Walt Disney Home Video, 2013. DVD.

Musker, John, Ron Clements. dir. Hercules. 1997; Burbank, CA: Walt Disney Home Video, 2002. DVD.

Scribner, George. dir. Oliver and Company. 1988; Burbank, CA: Walt Disney Home Video, 2008. DVD.

Trousdale, Gary, Kirk Wise. dir. Beauty and the Beast. 1991; Burbank, CA: Walt Disney Home Video, 2012. DVD.

Wise Kirk, Gary Trousdale. dir. The Hunchback of Notre Dame. 1996; Burbank, CA: Walt Disney Home Video, 2001. DVD. 